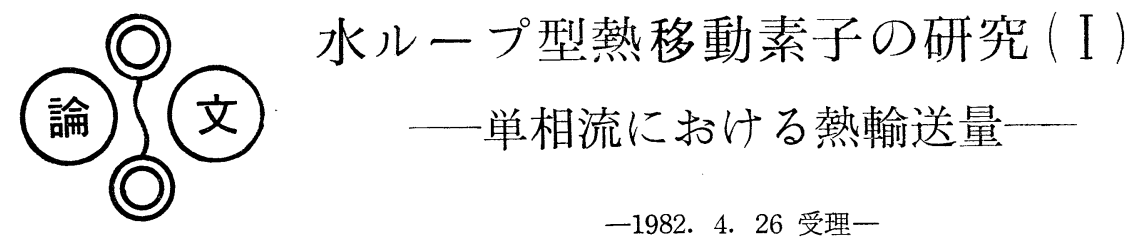

\author{
公害資源研究所* 山本 格, 田中芳雄, 鈴木善三 \\ 長岡技術科学大学** 服部久雄
}

\section{1. はじめに}

ループ型熱移動素子は，上昇管と下降管で構成され るループ状の管内に作動液を封入したものである。作 動液を循環するための駆動力は，上昇管と下降管内の 作動液の密度差で与えられる。作動液の循環により熱 は高熱源から低熱源へ移動するが，熱移動にヒートパ イプ（熱サイフォン）と同じように，蒸気移動を利用 することもできる。

ループ型熱移動素子は一種のヒートパイプとみなせ るが，ヒートパイプはそれ自身を基本単位として，モ ジュール的注組み立てて，たと党ば，熱回収装置を作 るのに対して,ループ型熱移動素子はモジュール的な 使用もできるが，多くはそれ自身でひとつの熱回収装 置を構成することができる。したがって，ヒートパイ プとループ型熱移動素子では，多くの場合その用途が 異なり，また，管体の形状，作動液の使用量などが異な るため, 両者の性能を単純に比較することはできない。 本研究は種々の作動液を用いるループ型熱移動素子 の性能予測に関するものであるが，本報では，その一 環として試作した水ループ型熱移動素子の熱輸送量に ついて検討した結果を報告する。

\section{2. ループ型熱移動素子}

\section{$2.1 ル ー フ ゚$ 型熱移動素子の基本形状}

ループ型熱移動素子の典型的な形状はFig. 1 亿示す ようなものであり，A・B両管の上部，下部が連結し て形成される閉回路内に適当量の作動液を封入したも のである。ここで，A管は上昇管，また，B管は下降 管をそれぞれ表わしている。

上昇管の下部 $\ell_{1}$ は加熱部, 下降管の上部 $\ell_{5}$ は冷却 部であり，その他の $\ell_{2}, \ell_{3}, \ell_{4}$ 打よび $\ell_{6}$ はそれぞれ断 熱部となっている。

\section{2 試作水ループ型熱移動素子}

* 公害第 4 部, 茨城県筑波郡谷田部町小野川16-3

** 長岡市富岡町字長峰1603-1

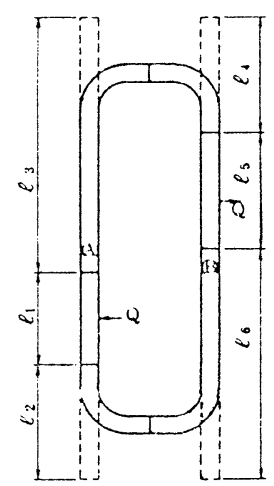

Fig. 1 Schematic diagram of looped type heat transport element

本実験で使用したループ型熱移動素子管体は, 内径 $15.6 \mathrm{~mm}$ の銅パイプで作られて和り，上昇管と下降管 の全高はいずれも $1,920 \mathrm{~mm}$ である。

作動液には水を使用し，下降管上部に設けられてい る後述の膨張タンク内の液面高さが，運転休止時で50 $\mathrm{mm}$ になるまで封入した。

作動液を加熱・冷却するための加熱器および冷却器 が，それぞれ上昇管下部より $185 \mathrm{~mm}$ の位置と下降管 上部から $75 \mathrm{~mm}$ の位置に, 供試熱移動素子管体の一部 として組み込まれている。

加熱器は12本のカートリッジヒータ $(\phi 16 \times 160 \mathrm{~mm}$, $640 \mathrm{~W} /$ 本) で構成される内熱式加熱器であり，十分な 保温を施してある。また，その表面には，熱損失量を 検出するための 4 個の熱流計センサーが取付けられて いる。

冷却器はシェルアンドチューブ式熱交換器で, その 寸法は流路方向に $200 \mathrm{~mm}$, 幅 $400 \mathrm{~mm}$, 奥行 $100 \mathrm{~mm}$ で ある。伝熱コアは $\phi 15 \mathrm{~mm}$ の銅伝熱管と厚み $0.6 \mathrm{~mm}$ の アルミプレートフィンで構成され, 総伝熱面積は 3.6 $\mathrm{m}^{2}$ である。作動液は管外, 冷却水は管内を流れる。

加熱器出口から $155 \mathrm{~mm}$ の位置に, 管内の水の流動 状態を観察するための観察空がある。

下降管上部には, 作動液の膨張, 圧力変動を吸収す 


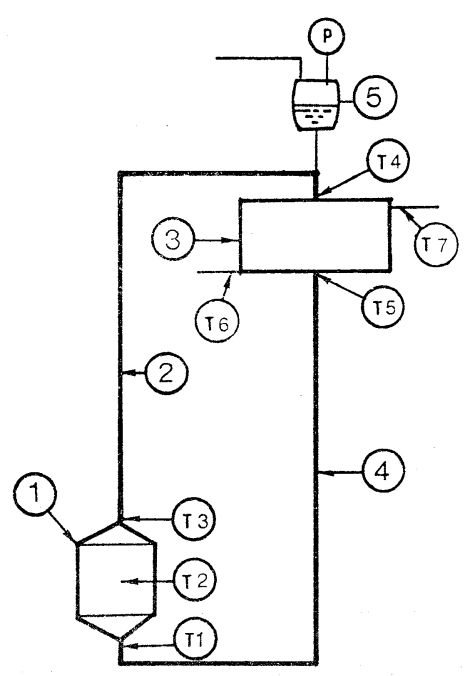

(1) Heater

(2) Riser tube

(3) Cooler

(4) Down comer

(5) Expansion tank

(T1)-(T5)

Thermocouples for temperature measurement of water in looped tube (T6)-(T7)

Thermocouples for temperature measurement of cooling water

Fig. 2 Schematic diagram of looped type heat transport element employing water as working fluid

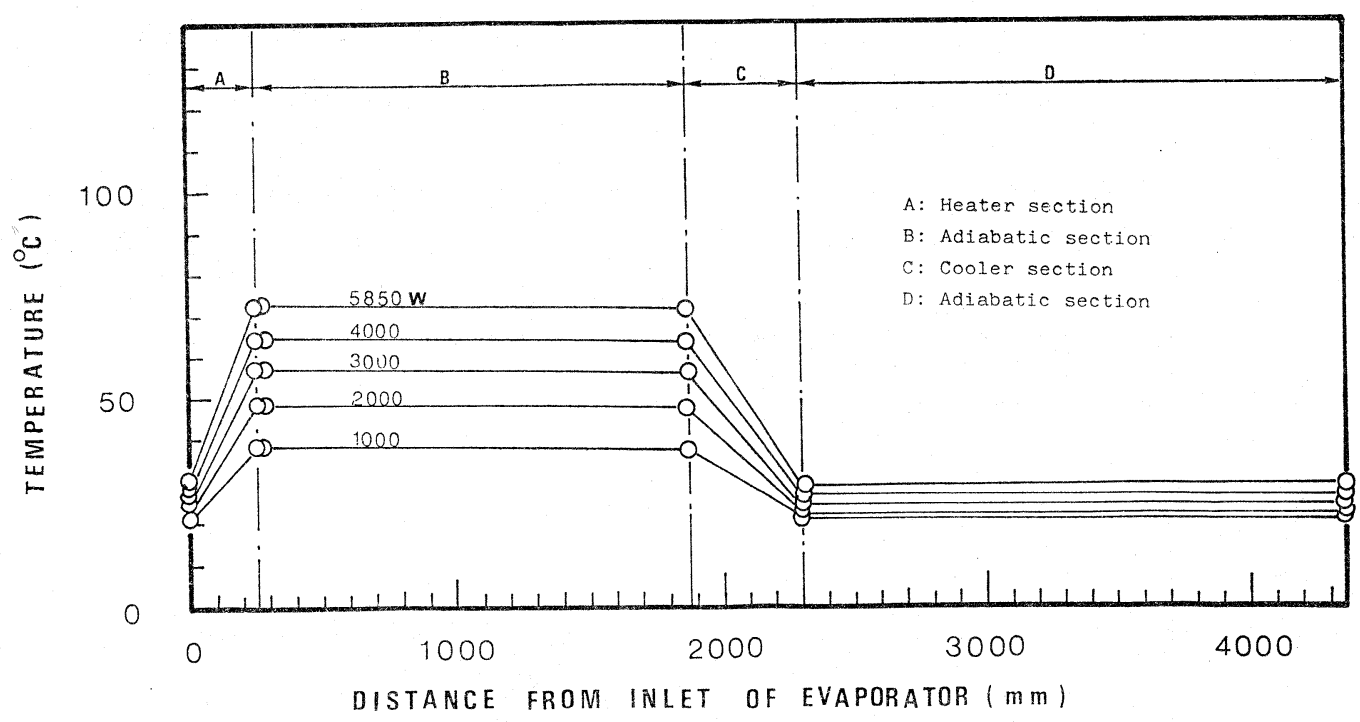

Fig. 3 Water temperature profile of looped type heat transport element

るための膨張タンクを設けてめる。系内圧力は大気圧 から $0.3 \mathrm{~kg} / \mathrm{cm}^{2} ・ \mathrm{G}$ 程度まで調整できる。圧力調整は, 膨張タンク内にアルゴンガスを注入して行う。

熱移動素子表面からの熱放散を防ぐため，素子全体 は十分に断熱保温を施してある。

\section{3. 実験装置と方法}

実験装置の系統図をFig. 2 に示す。装置は供試熱移 動素子, 加熱器用の電力供給装置, 冷却水の計量器, の三つの主要部分で構成されている。

加熱器の熱入力はデジタル積算ワットメータで測定
し, このメータ読取值より加熱器表面からの熱損失量 を差し引いた熱量を，正味の熱入力とした。

冷却器は作動液の冷却のほかに, カロリーメータと して使用する。このため, 冷却器入口・出口の冷却水 の温度および冷却水量を測定した。

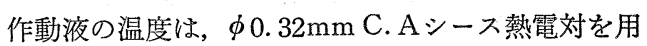
いて, 加熱器入口・出口括よび冷却器入口・出口の計 4 箇所で連続測定した。

実験は，和もに作動液が沸騰しない温度範囲内で, 冷却水量を設定条件として, 加熱器出口に和ける作動 
液の温度と熱輸送量の関係を求めた。

\section{4. 実験結果と考察}

供試ループ型熱移動素子の代表的な温度分布 の一例をFig. 3 亿示す。Fig. 3 の温度は, 冷却 水量を一定に設定した場合の加熱器入口・出口 特よび冷却器入口・出口での作動液の温度を表 わしている。

加熱器の熱入力の増加にともない, 各測定点 で温度上昇が認められるが，加熱器出口から泠 却器入口までの経路, また, 冷却器出口から加 熱器入口間での温度変化は非常に小さく, 素子 流路の保温状態はきわめて良好であることを示 して佂り，この図から，素子流路での熱損失は 無視できるほど小さいものと考觉られる。

試作熱移動素子の加熱部と冷却部での熱収支 はFig. 4 のようになり，加熱部で測定した熱入 力と冷却部で泠却水が持ち去る熱量との間には 良好な一致がみられ, 熱入力の 測定, 温度 測 定, 冷却水量の測定など本実験での計測方法は 妥当なるのと考光られる。それゆ光，本実験で は, 供試熱移動素子の熱輸送量を加熱器での熱入力と 冷却器での放出熱量との算術平均値で表わしている。

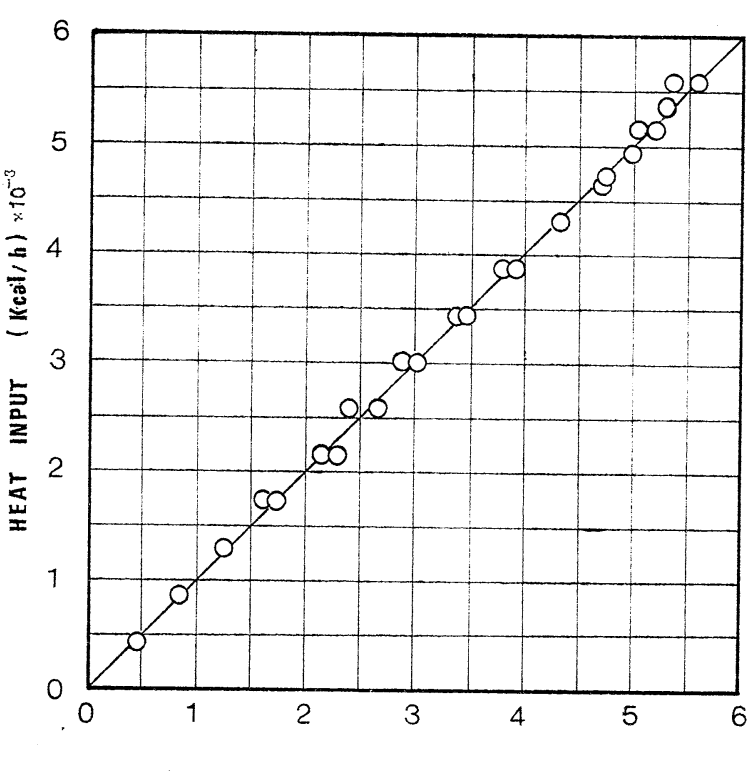

HEAT ABSORBED by COOLING WATER (Kcal/h) $\times 10^{-3}$

Fig. 4 Heat balance

ループ型熱移動素子の熱輸送量は, 冷却水量と冷却 水温度によって左右され, 冷却水量が多い注ど, ま

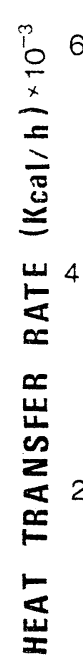

0

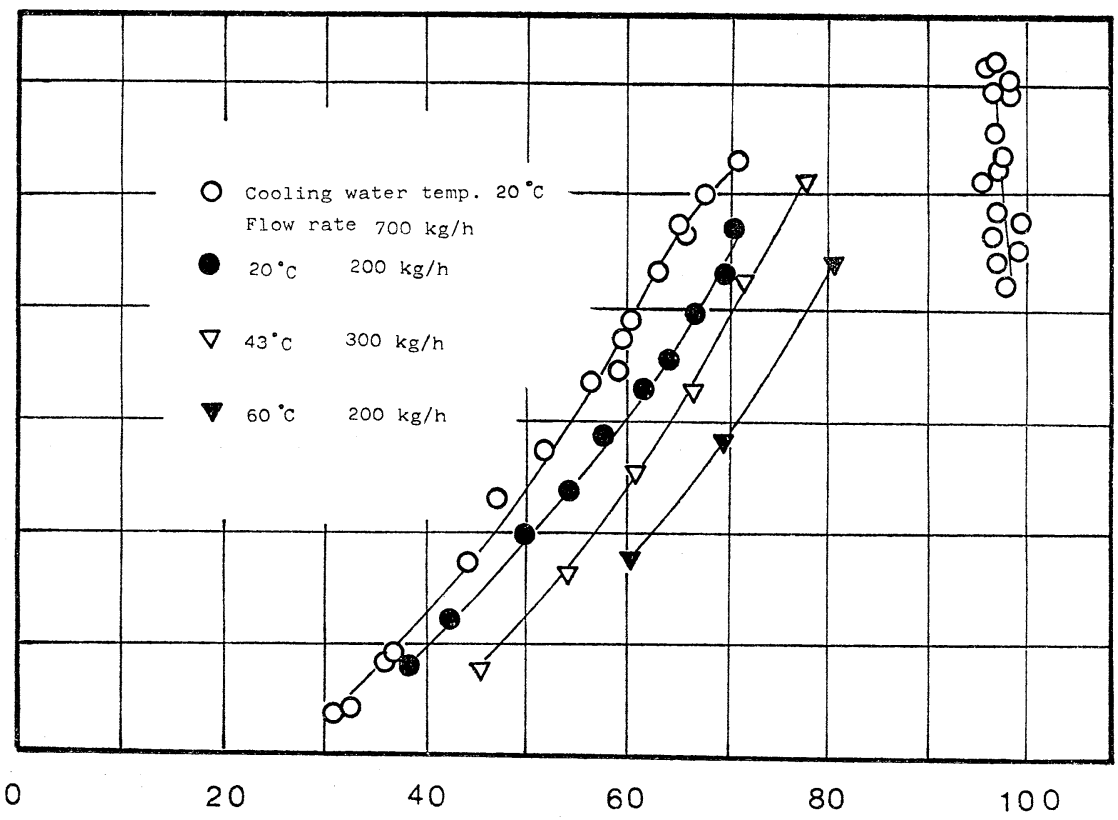

OUTLET WATER TEMPERATURE OF HEATER ('C)

Fig. 5 Effect of inlet water temperature of water cooler and flow rate of cooling water on heat transfer rate 
た，冷却水温が低いほど，熱輸送量は増加する。この 関係を冷却水量および冷却水温度をパラメータとし て, 加熱器出口温度に対して示したものがFig. 5 であ る。

Fig. 5 の実験範囲内では, 循環水の加熱器出口温度 の上昇とともに，熱輸送量曲線はいずれる増加してい るが, 加熱器出口温度が $90^{\circ} \mathrm{C}$ 程度に達すると, 熱輸送 量は急激に減少している。

本実験では，上昇管中のボィド率を測定していない ので，上昇管内の水の流動状態は目視観察によるか, 温度，圧力変動から推測せざるを得ないが，目視観察 では, 加熱器出口で水温が $90^{\circ} \mathrm{C}$ 以上に達すると, 上昇 管内の流孔は気ほう流からスラグ流へと遷移し，スラ グ流の発達とともに, 熱輸送量の減少が始まってい る。循環水の加熱器出口温度が $90^{\circ} \mathrm{C}$ 以下でも, しばし ば循環水中に気ほうの存在が観察されるが，本研究で は, 循環水の加熱器出口温度が $100^{\circ} \mathrm{C}$ 以下では循環水 の流動は完全な水単相流であると仮定し，Fig. 6 に示 すような簡単な計算モデルを用いて熱輸送量を推定す ることにした。

この計算・モデルでは, 循環水の流路を加熱器流路の 中間点から上昇管を経て冷却器流路の中間点までの高

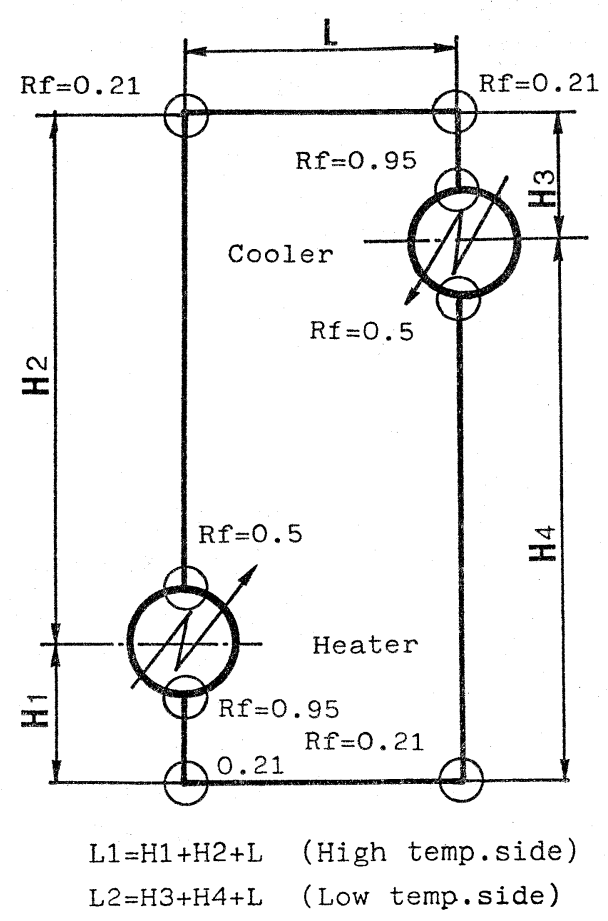

Fig. 6 Calculation model
温側流路と, 冷却器流路中間点から下降管を経由して 加熱器流路中間点までの低温側流路に分け，それぞれ の流路に打ける循環水の平均流速を求める。平均流速 を算出するにめたって, 各流路では循環水の温度は一 定とする。この仮定は，Fig. 3 の循環水の温度分布か ら見ても, 妥当なものと考光られる。

Fig. 6 の計算モデルに対して，ループ型熱移動素子 の循環の基礎式は次のように表わすことができる。

$$
\begin{aligned}
& \left(\mathrm{H}_{3} \gamma_{\mathrm{I}}+\mathrm{H}_{4} \gamma_{\mathrm{II}}\right)-\left(\mathrm{H}_{1} \gamma_{\mathbb{I}}+\mathrm{H}_{2} \gamma_{\mathrm{I}}\right) \\
& =\sum_{\mathrm{i}=1}^{\mathrm{n}} \mathrm{Rf}_{\mathrm{I}} \gamma_{1} \frac{\mathrm{u}_{\mathrm{I}}{ }^{2}}{2 \mathrm{~g}}+\mathrm{f}_{\mathrm{I}} \gamma_{\mathrm{I}} \frac{\ell_{\mathrm{I}}}{\mathrm{d}} \frac{\mathrm{u}_{1}{ }^{2}}{2 \mathrm{~g}} \\
& +\sum_{\mathrm{i}=1}^{\mathrm{n}} \mathrm{Rf}_{\mathbb{I I}} \gamma_{\mathbb{I}} \frac{\mathrm{u}_{\mathbb{I I}}{ }^{2}}{2 \mathrm{~g}}+\mathrm{f}_{\mathbb{I}} \gamma_{\mathbb{I}} \frac{\ell_{\mathbb{I}}}{\mathrm{d}} \frac{\mathrm{u}_{\mathbb{I}}{ }^{2}}{2 \mathrm{~g}}
\end{aligned}
$$

ここで, $\mathrm{H}$ : 図示した各点での位置水頭 $(\mathrm{m})$

$\ell:$ 高・低温側流路長さ $(\mathrm{m})$

$\gamma:$ 循環水の比重量 $\left(\mathrm{kg} / \mathrm{m}^{3}\right)$

$\mathrm{u}$ : 管内平均流速 $(\mathrm{m} / \mathrm{s})$

$\mathrm{f}$ : 管摩擦係数

流れが層流の場合, $\mathrm{f}=64 / \mathrm{Re}$ 流れが乱流の場合,

$$
f=0.3164 R e^{-0.25}
$$

Rf : ベンドなどの局所摩擦係数

添字 I，IIはそれぞれ高温側流路，低温側 流路を表わす。

完全な水単相の下で, 循環水を循環するための駆動 力が，上昇管内と下降管内の循環水の密度差で与えら れる場合の平均流速は, 加熱器の熱入熱に応じて, 次 の三つの場合に分けて考える必要がある。

1）高温側流路内と低温側流路内の流れがいずれも 乱流である場合。

2 ) 高温側流路内の流れは乱流で，低温側流路内の 流れが層流である場合。

3）両流路内の流れがいずれも層流である場合。

高温側流路内平均流速 $\mathrm{u}_{1}$ と低温側流路内平均流速 $\mathrm{u}_{\mathbb{1}}$ との間には，連続の式により，

$$
\mathrm{u}_{\mathrm{I}}=\mathrm{u}_{\mathbb{I}}\left(r_{1} / \gamma_{2}\right)
$$

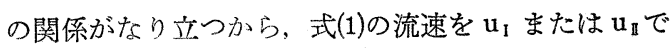
表わし，陚行錯誤法により $\mathrm{u}_{1}$ または $\mathrm{u}_{\mathbb{I I}}$ いずれかに ついて平均流速を求める。

素子内径を $\mathrm{d}(\mathrm{m})$ とすると, 循環水量 $(\mathrm{G})$ は次式 で与えられる。

$$
\mathrm{G}=3600 \cdot\left(\frac{1}{4}\right) \pi \mathrm{d}^{2} \cdot \gamma_{\mathrm{I}} \cdot \mathrm{u}_{1}(\mathrm{~kg} / \mathrm{h})
$$

また，加熱器入口温度 $20^{\circ} \mathrm{C}$ 基準における熱輸送量 


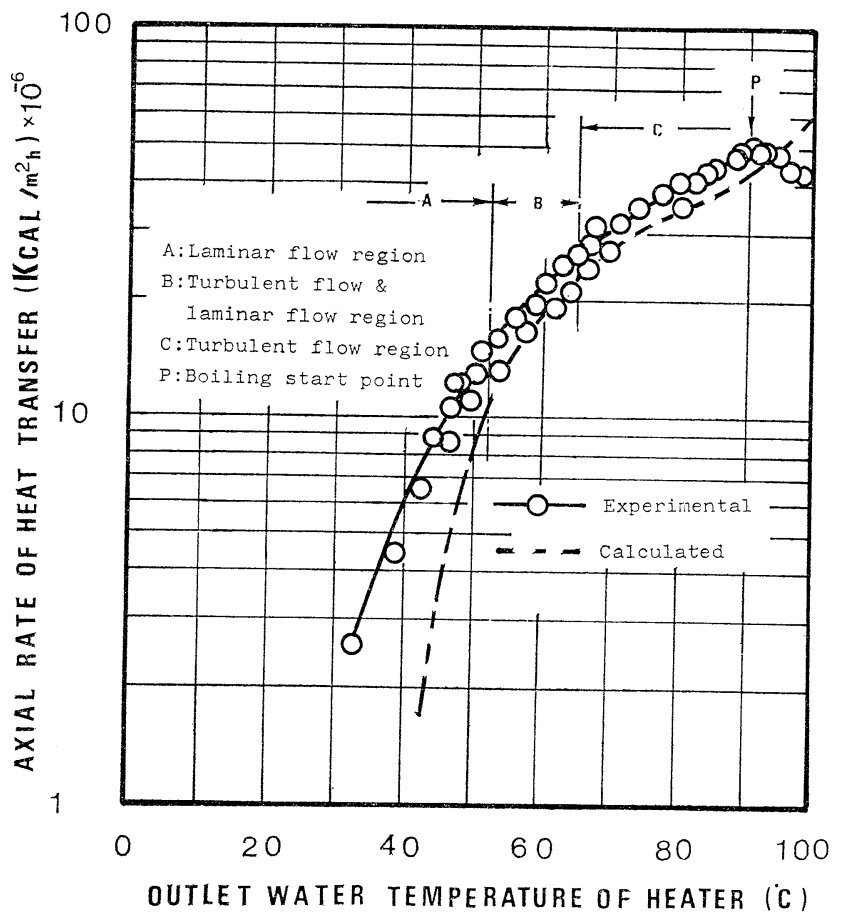

Fig. 7 Axial rate of heat transfer for heat transport element

(Q)は次式で得られる。

$$
\mathrm{Q}=\mathrm{Cp} \cdot \mathrm{G} \cdot\left(\mathrm{t}_{\mathrm{h}}-20\right) \quad(\mathrm{kcal} / \mathrm{h})
$$

ここで,

$\mathrm{Cp}:$ 循環水の比熱 $\left(\mathrm{kcal} / \mathrm{kg}{ }^{\circ} \mathrm{C}\right)$

$\mathrm{t}_{\mathrm{h}}$ : 加熱器出口に打沵る循環水の平均温度 ${ }^{\circ} \mathrm{C}$ 加熱器入口温度 $20^{\circ} \mathrm{C}$ 基準に打ける流路単位断面積, 単位時間当たりの熱輸送量 $\left(Q_{A}\right)$ は, 次式で得られる。

$$
\mathrm{Q}_{\mathrm{A}}=3600 \cdot \mathrm{Cp} \cdot \gamma_{\mathrm{I}} \cdot \mathrm{u}_{\mathrm{I}}\left(\mathrm{t}_{\mathrm{h}}-20\right) / \frac{1}{4} \pi \mathrm{d}^{2}
$$$$
\left(\mathrm{kcal} / \mathrm{m}^{2} \mathrm{~h}\right)
$$

式(5)で求められる熱移動素子の熱輸送量と実 験 值 を，加熱器出口温度に対して表わしたものがFig. 7 で ある。

高温側・低温側各流路内の流れは, レイノルズ数 $\operatorname{Re}$ が 2,300 程度までは層流であり， $\operatorname{Re}$ 数が大きく なると遷移域を経て乱流となる。これらの関係も， Fig. 7 の中に三つの領域に分けて示してある。すなわ ら, 第 1 の領域では, 両流路内の流れは層流である。 第2の領域においては，高温側流路内の流れは乱流と なるが，低温側流路内では，まだ層流である。第 3 の 領域では，両流路内の流れがともに乱流となってい る。

循環水の加熱器出口温度 $90^{\circ} \mathrm{C}$ 付近までは, 熱輸送量
の実験值は単調に増加しているが, $90^{\circ} \mathrm{C}$ 付近から熱輸送量は頭打らとなり，さら に昇温すると，熱輸送量は激しい変動を 呈しつつ減少傾向を示してくる。本実験 範囲内に拈ける試作熱移動素子の流路単 位断面積当たりの最大熱輸送量は $50 \times$ $10^{6}\left(\mathrm{kcal} / \mathrm{m}^{2} \mathrm{~h}\right)$ であり, $90^{\circ} \mathrm{C}$ 程度以上で は，目視観察からも，上昇管内の流れは 明らかに気・液二相流の状態となってい る。

上昇管内の流れの流動様式が気ほら流 であれば，駆動力を強め，循環水量を増 加することができるが，流れがスラグ流 まで発達すると，作動がきわめて不安定 となって, 循環水量が減少する。

熱輸送量の計算值と実験值を比較する と，両流路内の流れが層流である温度領 域と沸騰が生じている温度領域を除け ば，両値は非常に良く一致している。

二相流域で，式(5)による計算値と実測 値が相違することは当然であるが，両流 路とも層流になる領域で，実験值と計算 值の間に大きな差が生じ，実験值の方が 最大で 5 倍程度大きな值を示している。式(1)で各筒所 の局所摩擦係数を零と置いても，この差はさほど小さ くならない。筆者らは，式(5)による計算值と実験值と の相違について，原因を明らかにすることができな w。

\section{5. まとめ}

水ループ型熱移動素子について，熱輸送量を中心に 検討した。この結果，次の点が明らかとなった。

（1）単相流で循環する水ループ型熱移動素子の熱輸 送量は，高温側，低温側各流路内の流れが層流である 場合を除き，式(1)と式(5)から推定できる。

（2）本実験範囲内における供試熱移動素子の流路単 位断面積当たりの最大熱輸送量は $50 \times 10^{6} \mathrm{kcal} / \mathrm{m}^{2} \mathrm{~h}$ 程度である。これに対して，水を作動液とする同程度 の寸法のグルーブヒートパイプでは，最大熱輸送量は $30 \times 10^{6} \mathrm{kcal} / \mathrm{m}^{2} \mathrm{~h}$ 程度になる。したがって，単純な熱 輸送量の比較では，ループ型熱移動素子がすぐれてい るが，ループ型熱移動素子の作動液封入量は，ヒート パイプに比べ問題にならないほど多量である。そのた め，応答性は悪く，また，熱入力が過大になると，流 動状況が悪化，作動がきわめて不安定となるので，七 ートパイプに比べ，䩦しい使用温度範囲を定める必要 


\title{
Study on Looped Type Heat Transport Element Employing Water as Working Fluid ( I )
}

\author{
-On Heat Transfer Rate under Single Phase Flow- \\ Tadashi Yamamoto*, Yoshio TANAKA* Yoshizoo Suzuki*, \\ Hisao HATTORI** \\ $\left(\begin{array}{c}* \text { National Research Institute for Pollution and Resources } \\ * * \text { Nagaoka Gijutsu Kagaku University }\end{array}\right)$
}

SYNOPSIS:-In this paper, the results of the performance tests of the looped type heat transport element employing water as working fluid in the temperature range from 26 to $95^{\circ} \mathrm{C}$ at the outlet of the heating zone.

The container of heat transport element was fabricated from the looped copper tube consisted of riser tube and down comer with inner diameter $15.6 \mathrm{~mm}$. The total height of this element is $1972 \mathrm{~mm}$.

Electric heater for heating zone of element was mounted at the lower part of the riser tube and water cooler for heat removal from the element also was mounted at the upper part of the down comer.

As a result of this test, it can be concluded that the stable working region of this heat transport element depends on Reynolds number in the thoth tubes, that is, the flow in the tube of the high temperature side is turbulent flow and the flow of the low temperature side is the laminar flow.

\section{Key Words}

Looped type heat transport element, Riser tube, Down comer 